\title{
Lichen aureus with pseudolymphomatous infiltrate
}

Kolm, Isabel ; Buset, Caroline ; Flury, Ursula ; Nosek, Daniel ; Kazakov, Dmitry V ; Kempf, Werner

\begin{abstract}
Lichen aureus is a variant of pigmented purpuric dermatoses. The usual histopathology of lichen aureus is characterized by a subepidermal dense, band-like lymphocytic infiltrate, extravasated erythrocytes, and hemosiderin deposits. We report three patients with lichen aureus on the extremities with similar clinical, dermoscopic, and histopathological findings characterized by a dense band-like relatively deep dermal infiltrate accompanied by extravasation of erythrocytes and hemosiderin deposits occasioning a resemblance to a lymphoproliferative disorder. Keywords: lichen aureus; mycosis fungoides; pigmented purpuric dermatosis; pseudolymphoma.
\end{abstract}

DOI: https://doi.org/10.1111/cup.13948

Posted at the Zurich Open Repository and Archive, University of Zurich ZORA URL: https://doi.org/10.5167/uzh-209687

Journal Article

Accepted Version

Originally published at:

Kolm, Isabel; Buset, Caroline; Flury, Ursula; Nosek, Daniel; Kazakov, Dmitry V; Kempf, Werner (2021). Lichen aureus with pseudolymphomatous infiltrate. Journal of Cutaneous Pathology, 48(5):669-673.

DOI: https://doi.org/10.1111/cup.13948 


\title{
Glucocorticoid Receptor Beta and Its Prognostic Value on Treatment Response in Chronic Vulvar Dermatitis
}

\section{GR $\beta$ Expression in Chronic Vulvar Dermatitis}

Valerie Bernays ${ }^{\mathrm{a}}$, Mariusz Pawel Kowalewski ${ }^{\mathrm{b}}$, Ioannis Dedes ${ }^{\mathrm{a}}$, Katrin Kerl French ${ }^{\mathrm{c}}$, Daniel Fink ${ }^{\mathrm{a}}$, Isabel Kolm ${ }^{\mathrm{c}}$ and Cornelia Betschart ${ }^{\mathrm{a}}$

${ }^{a}$ Department of Gynecology, University Hospital Zurich, [Comment: Please add after University Hopsital Zurich, University of Zurich the affiliation with the University of Zurich, should also be inserted for the authors of the Department onf Dermatology. It was forgotten for the University Hospital Zurich affiliations (a and c). For the Institute of Veterinary Anatomy it is correct. Thank you.]Zurich, Switzerland

${ }^{b}$ Institute of Veterinary Anatomy, Vetsuisse Faculty, University of Zurich, Zurich, Switzerland

${ }^{\mathrm{c} D e p a r t m e n t ~ o f ~ D e r m a t o l o g y, ~ U n i v e r s i t y ~ H o s p i t a l ~ Z u r i c h, ~ Z u r i c h, ~ S w i t z e r l a n d ~}$

Cornelia Betschart, Department of Gynecology, University Hospital Zurich, Frauenklinikstrasse 10, CH-8091

Zürich (Switzerland), E-Mail Cornelia.Betschart@usz.ch

I.K. and C.B. contributed equally to the study.

\begin{abstract}

\section{Background}

Chronic vulvar dermatitis (CVD) is the most prevalent disease in gynecologic dermatology. The treatment mainly depends on topical glucocorticoids (TGC) but is challenged by insufficient treatment response. On a histological level, the upregulation of the glucocorticoid receptor $\beta$ (GR $\beta$ ), an inhibitor of the active glucocorticoid receptor $\alpha(\mathrm{GR} \alpha)$, is discussed as mechanism of glucocorticoid insensitivity.
\end{abstract}

\section{Objectives}

ŁTo analyze whether the expression of GR $\beta$ protein at baseline in keratinocytes may predict responsiveness to TGC in patients with CVD.

\section{Methods}

In this retrospective cohort study, clinical and biological data of 25 women with a histological diagnosis of chronic vulvar eczema were analyzed. Randomization was done according to the responsiveness to TGC treatment (responsive vs. nonresponsive). Clinical data and the expression of GR $\beta$ in the immunohistochemical stained biopsies were examined.

\section{Results}

Fifty-two percent of women with CVD were nonresponsive to TGC. GR $\beta$ was abundantly expressed in the cytoplasma of keratinocytes of the vulvar epithelium, but no difference in the level of expression was found among GC responsive and nonresponsive patients in the semiquantitative $(p=0.376)$ and quantitative analysis $(p=0.894)$.

\section{Conclusion}


GR $\beta$ is highly expressed in keratinocytes of the vulvar epidermis affected by CVD, but GR $\beta$ expression was not increased in patients nonresponsive to TGC compared to responsive patients. Thus, the failure mechanism in nonresponders still remains to be elucidated.

Keywords: Chronic vulvar dermatitis; Glucocorticoids; Glucocorticoid insensitivity; Glucocorticoid receptor beta; Keratinocytes

\section{Introduction}

Vulvar dermatitis is the most common disease in specialized vulvar clinics [1]. The most frequent cause of vulvar eczema is atopic eczema followed by irritant and allergic contact eczema [2].

Symptoms of vulvar eczema are pruritus, burning, and dyspareunia [3,4]. Vulvar eczema often undergoes a chronic course which can lead to a significant impact on the quality of life of the affected women $[5,6]$. Diagnosis of vulvar eczema is made according to the patient's history, clinical examination, and histopathology.

Topical glucocorticoids (TGC) are the first-line therapy for vulvar dermatitis though glucocorticoid (GC) insensitivity is thought to play an important role in treatment failure [7-9]. Glucocorticoids exert their anti-inflammatory and immunosuppressive effect by binding the intracellular-located glucocorticoid receptor (GR), belonging to the nuclear receptors superfamily of ligand-dependent transcription factors $[10,11]$. The GR is encoded by a single gene composed as a modular protein consisting of 3 domains: an N-terminal transactivation domain, a central DNA-binding domain, and a C-terminal ligand-binding domain [12]. The 2 most important isoforms are GR alpha (GR $\alpha$ ) and beta (GR $\beta$ ) which arise from alternative splicing differing in their last 9th exon [11, 13].

GR $\alpha$ and $\beta$ are expressed in most human tissue and cell lines but generally GR $\beta$ is expressed at a lower level than GR $\alpha$ [13]. However, GR $\beta$ was found to be abundant in keratinocytes and cutaneous lymphocytes in inflammatory dermatoses [14]. Only GR $\alpha$ located unliganded in the cytoplasm is able to bind GC, translocate to the nucleus, dimerize and bind GC-responsive elements and therefore down- or upregulate the expression of glucocorticoidresponsive genes [13]. GR $\beta$ is unable to bind GC itself but is discussed as an inhibitor of GR $\alpha$ while its precise function remains unclear [13].

In several inflammatory diseases, for example, asthma, chronic rhinitis, or atopic dermatitis, treatment success is limited due to GC insensitivity. An upregulation of GR $\beta$ has been described as related to an insensitivity toward GC treatment; however, contradictory data are available [14-18]. The relevance of the expression of GR $\beta$ in patients with eczema who are insensitive to TGC treatment remains unclear. To our best knowledge, the expression of GR $\beta$ in vulvar eczema has not yet been studied. The objective of this study was to determine whether the expression of GR $\beta$ at baseline in keratinocytes of the vulvar epidermis varies among patients responsive and nonresponsive toward TGC treatment.

\section{Material and Methods}

\section{Subjects}

After a review of clinical data and tissue specimens, twenty-five $(n=25)$ female patients treated at the Department of Gynecology of the University Hospital Zurich, Switzerland, between 2016 and 2018 were included in this study. All patients had a clinical and histologically confirmed diagnosis of chronic vulvar dermatitis (CVD). Biopsies were taken after at least 3 months of TGC pause. Treatment and follow-up consultations up to 12 months regarding responsiveness were documented. The research project was approved and registered by the Swiss Ethics Committee (no. BASEC 2019-00037), and a general informed consent for further data and tissue use was obtained from all patients.

All clinical and histological data were pseudonymized (6-digit number). The observers (V.B. and M.P.K.) who conducted further analyses were blinded.

\section{Treatment}

Women with diffuse erythema and light symptoms were considered to have mild eczema, receiving a topical corticosteroid ointment with low to moderate potency (class I \& II: hydrocortisone acetate $25 \mathrm{mg} / \mathrm{g}$ or prednisolone acetate $25 \mathrm{mg} / \mathrm{g}$ ). Women with prominent skin changes (redness and thickening of the skin, blisters, excoriations, and 
fissures) and severe impact on their quality of life (severe itching and pain) were considered to have severe eczema, receiving a potent topical steroid (class III [mometasone-17-furoate, $1 \mathrm{mg} / \mathrm{g}$ ] or IV [clobetasol-17-propionate 0.5 $\mathrm{mg} / \mathrm{g}])$. The patients were instructed to apply the GC ointment twice daily for 2 weeks and then taper down. In case of relapse, the therapy could be resumed for up to 6 months [19].

Follow-up consultations were scheduled first between 2 weeks and 6 months after the first consultation, depending on the severity of symptoms, and ended after 12 months. Participants were divided into 2 groups according to their subjective treatment response: responders (remission of symptoms) and nonresponders (insufficient or absent ease of symptoms after at least 2 weeks of treatment).

\section{Tissue Sample}

Four-mm punch biopsies were obtained and underwent routine histopathologic procedures at the Dermatopathology Laboratory of the Department of Dermatology, University Hospital Zurich. Hematoxylin-eosin (HE) stains were evaluated by 2 trained dermatopathologists (K.K. and I.K.) experienced in the diagnosis of vulvar pathologies.

The histopathological diagnosis of eczema was established on HE stains based on the presence of the following criteria: epithelial changes (acanthosis, spongiosis, exocytosis of lymphocytes, and parakeratosis) and presence of an inflammatory infiltrate in the lamina propria. Periodic acid-Schiff and elastica stainings were routinely performed to exclude mycosis and lichen sclerosus, respectively.

\section{Immunohistochemistry}

An indirect immunoperoxidase immunohistochemistry (IHC) assay was performed using Vectastain ABC kit (Vector Laboratories). The primary antibody was a rabbit polyclonal antibody (IgG) against human GR $\beta$, dilution 1:2,000 in IHC buffer (ab3581; Abcam, Cambridge, UK). Nonimmunized rabbit IgG (isotype control) (rabbit IgG, I-1000; Vector Laboratories, Burlingame, CA, USA) was used to perform isotype control, and for negative control, the primary antibody was omitted. Human lung tissue served as a positive control, as recommended by the manufacturer. Controls are presented in Figure 1.

\section{Fig. 1.}

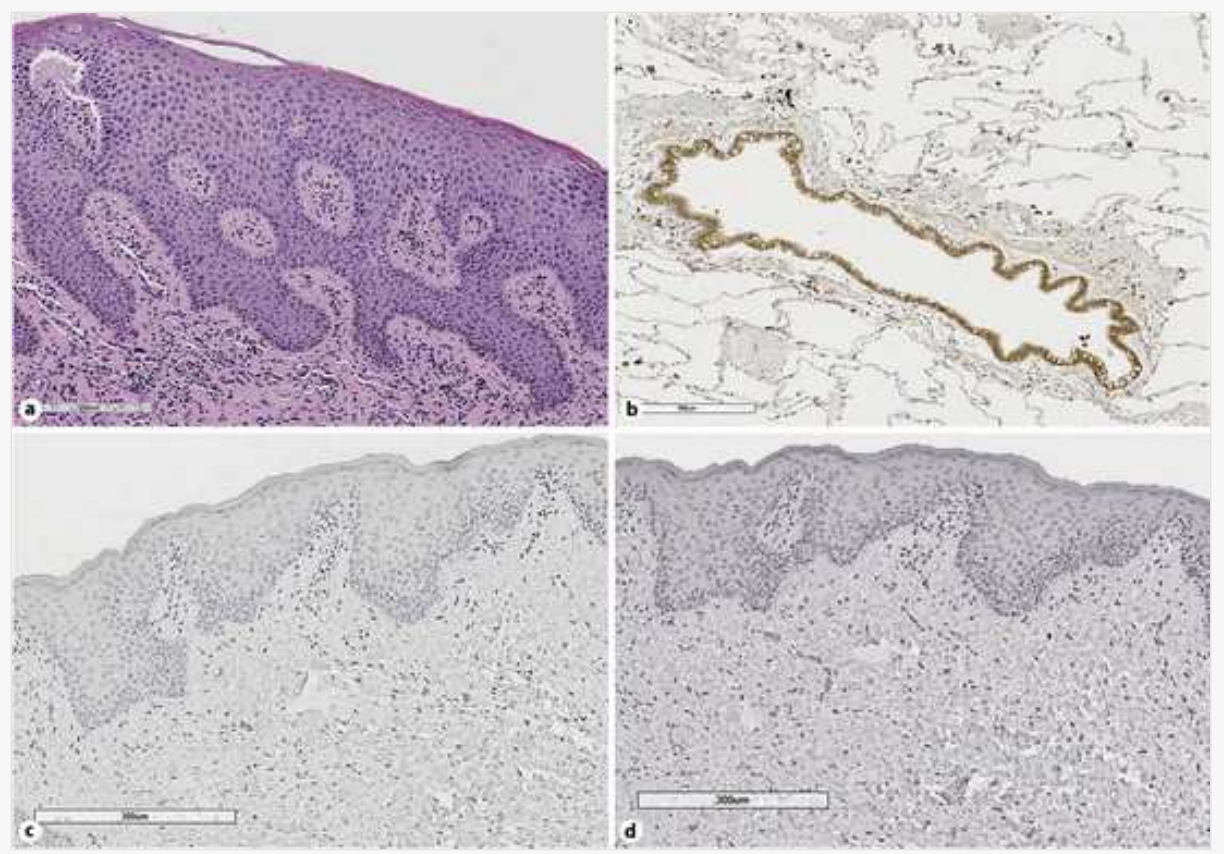

a HE stain of CVD with pronounced acanthosis and spongiosis, exocytosis of lymphocytes, and mild hyperparakeratosis. Marked inflammatory perivascular infiltrate and pigment incontinence in the lamina propria. b Alveolar epithelium as positive control tissue immunohistochemical stained with GR $\beta$; mast cell stain also positive for GR $\beta$. c Isotype control on vulvar tissue with nonimmunized rabbit IgG. d Negative control on vulvar tissue omitting the primary antibody. HE, hematoxylin-eosin; CVD, chronic vulvar dermatitis. 
The images were captured using an RGB color video camera (DFC 295; Leica, Wetzlar, Germany) attached to a light microscope (DMI 6000B; Leica, Wetzlar, Germany), NA 0.3, ×10 magnification. Three images per sample were captured showing representative histopathologic features of eczema. Color density and white balance were standardized for all images. Image analysis of the epidermal component was performed using the IHC Profiler plugin for ImageJ version 1 (NIH; Bethesda, MD, USA) (Java 1.8.9_66). A semiquantitative score was assigned accordingly: high positive, positive, low positive, and negative [20]. The optical density score was calculated out of the score generated via the IHC Profiler for quantitative analysis [21]. The intraclass correlation coefficient was calculated for 5 samples with excellent correlation results (0.975). Therefore, we analyzed 1 image per patient for final calculations. A trained specialist (I.K.) performed a semiquantitative analysis of the perivascular infiltrate (light/moderate/severe) with special interest in the expression of GR $\beta$ protein in inflammatory cells.

\section{Statistics}

In this retrospective cohort study, statistical analysis was performed with the SPSS software package (23.0, SPSS Inc., Chicago, IL, USA). In the descriptive analysis percentages, mean and standard deviation or median and interquartile distance were calculated for clinical, pharmacological, and immunohistochemical variables as appropriate. MannWhitney $\mathrm{U}$ test was used to compare values from the treatment response and immunohistochemistry in GC responsive and nonresponsive patients. The level of significance was set at $p<0.05, p<0.07$ was set as tendency, 1 sided. Because data concerning the mean and standard deviation of GR $\beta$ expression in CVD were not available when this project was begun, no power calculation was possible at the beginning of the study. Previous studies on the GR expression in inflammatory dermatoses or rheumatoid arthritis were done with collectives of 15, 13, and resp. 15 patients $[14,22,23]$. As the number of participants was $<30$, exact significances were used.

\section{Results}

\section{Baseline Characteristics}

The baseline characteristics are listed according to responders and nonresponders. Group comparison was made and expressed as $p$ values. Most women with CVD were premenopausal (77\%). Atopic predisposition was very common (11/17 patients: positive prick test and/or elevated serum IgE) (Table 1).

\section{Table 1.}

i) The table layout displayed in this section is not how it will appear in the final version. The representation below is solely purposed for providing corrections to the table. To preview the actual presentation of the table, please view the Proof.

Demographic data, irritative symptoms, atopic predisposition, allergological testings, and gynecological examination, $n=25$

\begin{tabular}{|c|c|c|c|}
\hline & Responders $(n=12)$ & Nonresponders $(n=13)$ & $p$ value \\
\hline Age (mean) & 38.7 & 37.9 & 0.915 \\
\hline \multicolumn{4}{|l|}{ Clinical hormonal status, $\%(n / N)$} \\
\hline Premenopausal & $75(9 / 12)$ & $76.9(10 / 13)$ & \multirow{3}{*}{0.611} \\
\hline Perimenopausal & $8.3(1 / 12)$ & $0(0 / 13)$ & \\
\hline Postmenopausal & $16.7(2 / 12)$ & $23.1(3 / 13)$ & \\
\hline Hormonal contraception, $\%(n / N)$ & $50(6 / 12)$ & $30.8(4 / 13)$ & 0.650 \\
\hline \multicolumn{4}{|l|}{ Comorbidities, $\%(n / N)$} \\
\hline Endometriosis & $8.3(1 / 12)$ & $7.7(1 / 13)$ & \multirow{2}{*}{0.769} \\
\hline Hemochromatosis & & $7.7(1 / 13)$ & \\
\hline
\end{tabular}

Irritative symptoms, $\%(n / N)$ 


\begin{tabular}{|c|c|c|c|}
\hline Burning sensation & $41.7(5 / 12)$ & $84.6(11 / 13)$ & 0.110 \\
\hline Vulvar pain & $75(9 / 12)$ & $61.5(8 / 13)$ & 1 \\
\hline Dyspareunia & $66.7(8 / 12)$ & $69.3(9 / 13)$ & 0.320 \\
\hline Atopic predisposition, $\%(n / N)$ & $91.7(11 / 12)$ & $46.2(6 / 13)$ & 0.077 \\
\hline Atopic dermatitis & $25(3 / 12)$ & $0(0 / 13)$ & 0.295 \\
\hline Allergic rhinitis/conjunctivitis & $25(3 / 12)$ & $38.5(5 / 13)$ & 0.611 \\
\hline Asthma & $16.7(2 / 12)$ & $7.7(1 / 13)$ & 0.979 \\
\hline Positive family history of atopy & $66.7(8 / 12)$ & $23.1(3 / 13)$ & 0.225 \\
\hline \multicolumn{4}{|l|}{ Allergological testings, $\%(n / N)$} \\
\hline Positive skin prick testing & $5(9 / 12)$ & $61.5(8 / 13)$ & 0.650 \\
\hline Elevated serum IgE $(>100 \mathrm{kU} / \mathrm{L})$ & $50(6 / 12)$ & $38.5(5 / 13)$ & 0.852 \\
\hline Positive patch testing & $16.7(2 / 12)$ & $0(0 / 13)$ & 0.406 \\
\hline Nickel & $33.4(4 / 12)$ & $23.1(3 / 13)$ & \\
\hline Amerchol L-101 & $25(3 / 12)$ & - & \\
\hline Glucocorticoids & $0(0 / 12)$ & $0(0 / 13)$ & \\
\hline \multicolumn{4}{|c|}{ Gynecological examination of the vulva, $\%(n / N)$} \\
\hline Vulvar erythema & $66.7(8 / 12)$ & $100(13 / 13)$ & 0.168 \\
\hline Dryness & $41.7(5 / 12)$ & $30.8(4 / 13)$ & 0.650 \\
\hline Edema & $8.3(1 / 12)$ & $7.7(1 / 13)$ & 0.979 \\
\hline Thickening of the skin & $50(6 / 12)$ & $15.4(2 / 13)$ & 0.152 \\
\hline Excoriations & $16.7(2 / 12)$ & $0(0 / 13)$ & 0.503 \\
\hline Fissures & $16.7(2 / 12)$ & $15.4(2 / 13)$ & 0.979 \\
\hline Blisters & $0(0 / 12)$ & $0(0 / 13)$ & 0.650 \\
\hline
\end{tabular}

\section{Histology}

A total of 25 vulvar biopsies were included. Twenty-one specimens were taken from the vulvar mucosae (in 18/21 cases of the introitus and in 3/21 cases of the labia minora) and 4 specimens showed keratinized epithelium (in 2/4 of the labia minora and in 2/4 of the labia majora). The histological findings are presented in Table 2.

\section{Table 2.}

(i) The table layout displayed in this section is not how it will appear in the final version. The representation below is solely purposed for providing corrections to the table. To preview the actual presentation of the table, please view the Proof.

Histological findings, $n=25$

\begin{tabular}{|c|c|c|c|}
\hline & Responders $(n=12)$ & Nonresponders $(n=13)$ & $p$ value \\
\hline Acanthosis, $\%(n / N)$ & $100(12 / 12)$ & $100(13 / 13)$ & 1 \\
\hline Spongiosis, \% $(n / N)$ & $75(9 / 12)$ & $38.5(5 / 13)$ & 0.123 \\
\hline Hyper/parakeratosis, $\%(n / N)$ & $83.3(10 / 12)$ & $76.9(10 / 13)$ & 0.810 \\
\hline Intraepithelial lymphocytes, $\%(n / N)$ & $91.7(11 / 12)$ & $100(13 / 13)$ & 0.728 \\
\hline
\end{tabular}

Perivascular infiltrate in the lamina propria, $\%(n / N)$ 


\begin{tabular}{|c|c|c|c|}
\hline Mild & $58.3(7 / 12)$ & $38.5(5 / 13)$ & 0.376 \\
\hline Moderate & $33.3(4 / 12)$ & $46.2(6 / 13)$ & \\
\hline Severe & $8.3(1 / 12)$ & $15.4(2 / 13)$ & \\
\hline Presence of eosinophilic granulocytes, $\%(n / N)$ & $41.7(5 / 12)$ & $15.4(2 / 13)$ & 0.052 \\
\hline
\end{tabular}

\section{Glucocorticoid Treatment}

Most patients had a history of previous treatments with TGC (16/25), topical antimycotics (21/25), and emollients $(25 / 25)$. Treatment responses related to GC potency are shown in Table 3. No significant difference between treatment response and TGC potency class was found in our study group $(p=0.848)$.

Table 3.

(i) The table layout displayed in this section is not how it will appear in the final version. The representation below is solely purposed for providing corrections to the table. To preview the actual presentation of the table, please view the Proof.

Treatment response related to TGC class, $n=25$

\begin{tabular}{|c|c|c|c|}
\hline & Responders $(n=12)$ & Nonresponders $(n=13)$ & $p$ value \\
\hline TGC class I & 6 & 7 & \\
\hline TGC class III/IV & 6 & 6 & \\
\hline Total, $\%(n / N)$ & $48(12 / 25)$ & $52(13 / 25)$ & 0.848 \\
\hline
\end{tabular}

TGC, topical glucocorticoids.

\section{Expression of GR $\beta$}

\section{Epithelium}

We detected positive cytoplasmic staining with GR $\beta$ in a large part of the keratinocytes in all tissue samples (25/25) with a predominant expression in the basal layer in $92.3 \%$ (24/25) of the cases. We found a positive nuclear GR $\beta$ staining of the keratinocytes (13/25) in half of the samples, restricted to different levels of the epithelium as demonstrated in Table 4. We found no difference in the expression of GR $\beta$ among mucosa and keratinized epithelium $(p=0.322)$.

Table 4.

(i) The table layout displayed in this section is not how it will appear in the final version. The representation below is solely purposed for providing corrections to the table. To preview the actual presentation of the table, please view the Proof.

Analysis of the nuclear GR $\beta$ expression and semiquantitative and quantitative analysis of the total amount of GR $\beta$ expression with IHC Profiler and IHC optical density score in the epithelium comparing responders and nonresponders to TGC treatment

\begin{tabular}{|c|c|c|c|c|}
\hline & Responders $(n=12)$ & Nonresponders $(n=13)$ & Total & $p$ value \\
\hline \multicolumn{5}{|l|}{ Nuclear GR $\beta$ staining, $n / N(\%)$} \\
\hline Positive & $4 / 12(33.3)$ & $9 / 13(69.2)$ & $13 / 25(52)$ & \multirow[t]{4}{*}{0.251} \\
\hline Upper part of the spinous layer & $1 / 12(8.3)$ & $4 / 13(30.8)$ & $5 / 25(20)$ & \\
\hline Lower part of the spinous layer & $2 / 12(16.7)$ & $2 / 13(15.4)$ & $4 / 25(16)$ & \\
\hline Basal layer & $1 / 12(8.3)$ & $3 / 13(23.1)$ & $4 / 25(16)$ & \\
\hline
\end{tabular}


Semiquantitative, $n / N(\%)$

\begin{tabular}{|l|l|l|l|l|}
\hline Low positive & 6 & 5 & $11 / 25(44)$ & \\
\hline Positive & 5 & 4 & $10 / 25(40)$ & 0.376 \\
\hline High positive & 1 & 3 & $5 / 25(20)$ & \\
\hline Quantitative & & & 0.894 \\
\hline IHC optical density score, mean (SD) & $2.29(0.62)$ & $2.40(0.82)$ & \\
\hline
\end{tabular}

GR $\beta$, glucocorticoid receptor $\beta$; IHC, immunohistochemistry; TGC, topical glucocorticoids.

The total amount of expression of GR $\beta$ protein varied among the samples as demonstrated in Figure 2 and Table 4. There were no significant differences in the expression of the total amount (semiquantitative: $p=0.376$ and quantitative: $p=0.894)$ or the positive nuclear staining of GR $\beta(p=0.251)$ in the epithelium when comparing responsive patients with those nonresponsive to TGC treatment. However, we found positive nuclear staining more frequently in nonresponders (69.2\%) than in responders (33.3\%). 
Representative photomicrographs of immunohistochemical GR $\beta$ staining of vulvar tissue specimens affected by CVD. Hematoxylin was used as a counterstain. Staining intensities represent the categories high positive (a), positive (b), and low positive (c) of the semiquantitative scoring system. GR $\beta$, glucocorticoid receptor $\beta$; CVD, chronic vulvar dermatitis.

\section{Lamina Propria}

We found no difference in the density of the inflammatory infiltrate among responders and nonresponders as shown in Table 2. Analysis of the inflammatory cells in the lamina propria showed positive GR $\beta$ expression in the lymphocytes and mast cells in all tissue samples while eosinophilic or neutrophilic granulocytes did not express GR $\beta$. In addition to the inflammatory cells, we also found positive expression of GR $\beta$ in vascular endothelial cells as previously described in literature [14, 24].

\section{Discussion}

In this retrospective study, we analyzed GC responsiveness in CVD related to the expression of GR $\beta$ in keratinocytes of the vulvar epithelium. GC insensitivity is a multifactorial problem challenging the treatment of various inflammatory and autoimmune diseases [10]. TGC treatment led to complete remission of symptoms in only half of the patients $(48 \%)$, while in $52 \%$ the treatment was not or not sustainably successful. One suggested molecular mechanism decreasing the anti-inflammatory effect of GCs is the upregulation of GR $\beta[10,25]$.

We detected abundant GR $\beta$ protein expression at the whole cell level in keratinocytes in all the vulvar tissue samples. Skin samples from patients with inflammatory skin disorders showed similar expression of GR $\beta[14,26]$, whereas the protein is little expressed in most of the healthy human tissues and cell types [27, 28].

This is supported by the finding that a dysregulation of the endogenous skin GC production can play a key role in skin inflammatory disorders [29]. Human skin cells express the full cytochrome P450 side-chain cleavage system involved in steroid synthesis [30] as well as key high-level regulators such as corticotropin-releasing hormone, propriomelanocortin, and ACTH [31][32], which can be stimulated by stressors such as UVB or inflammation [32]. It seems possible that this peripheral endogenous GC production is involved in the regulation of the expression of GR $\beta$.

Modulators of GR $\beta$ expression include cytokines [33, 34], microbial antigens [4, 35], and superantigens [15]. Notably, streptococcal and staphylococcal antigens are highly prevalent on the skin [36]. These mechanisms might have contributed to the similarly high expression of GR $\beta$ in CVD.

Expression of the GR $\beta$ protein was predominantly found in the cytoplasm of keratinocytes, whereas nuclear staining of GR $\beta$ was only seen in few cases. This may be explained by the fact that GR $\beta$ can interfere with GR $\alpha$ on a nuclear level and affect its mediated gene repression [37].

GR $\beta$ staining in the epithelium did not show any significant differences among responders and nonresponders to TGC treatment. While this finding is consistent with research on atopic dermatitis [14], GC-resistant patients in other inflammatory diseases, for example, asthma, were shown to have an increased expression of GR $\beta$ [14, 17, 38-41]. The function of GR $\beta$ likely depends on the involved cell types and may be modulated by disease-specific factors such as cytokines [42]. Intracrinology plays a role in the sex steroid physiology in women (E2 and testosterone) as appropriate intracellular steroid-inactivating enzymes prevent the release of biologically significant amount of E2 or testosterone into the circulation, thus avoiding inappropriate action in the other tissues [43]. Whether intracrinology applies to GC synthesis and contributes to different responsiveness in CVD has to be further elucidated.

As we focused on the epidermal expression of GR $\beta$, future studies should address the expression of GR $\beta$ of the dermal component omitting the vascular endothelia. Laser capture microdissection may be predisposed for such work. After 
extraction of the RNA and complementary DNA, a quantitative real-time PCR using primers for GR $\beta$ and the housekeeping gene would reveal the amount of steroid receptor expression in this specific layer [44].

The application of TGC is described to alter the GR profile [14]. We can discard this factor as none of the patients received TGC or systemic steroids at least 3 months prior to the enrollment in the present study. We were not able to show a difference between the applied TGC potency and treatment response but may have missed such an effect because of the small number of study participants. It is worth noting that the quantification of treatment response in CVD with a standardized recording, for example, the Dermatology Life Quality Index, is not established. We chose an immunohistochemical GR antibody, which was successfully applied in previous studies. However, the fact that there are different immunohistochemical GR antibodies and quantification methods needs to be considered when comparing the literature. Computerized image analysis was used to avoid bias.

The remarkable expression of GR $\beta$ in CVD demonstrated herein predisposes this common disease for future studies analyzing the yet not fully understood function of GR $\beta$ [45]. More knowledge of the role of GR $\beta$ will contribute to a better understanding of its involvement in GC insensitivity and might result in novel treatment strategies for GCinsensitive patients.

In summary, our study reveals that keratinocytes of the vulvar epithelium of patients with CVD abundantly express GR $\beta$ protein regardless of TGC responsiveness or nonresponsiveness. Further studies are needed to elucidate the function of GR $\beta$ in CVD and its impact on treatment response. Our results suggest that other aspects than the expression of GR $\beta$ have to be taken into consideration for treatment success in CVD.

\section{Acknowledgements}

We thank Etienne Groepl for his excellent technical support in immunohistochemical staining, Dr. med. Morteza Jafari and Prof. Dr. sc. nat. Manuel Stucki for the support in image analysis and Carla Trachsel for her meticulous linguistic revision of the manuscript.

\section{Statement of Ethics}

A general informed consent for further data and tissue use had previously been obtained from all patients. The research project was approved and registered by the Swiss Ethics Committee (no. BASEC 2019-00037).

\section{Conflict of Interest Statement}

The authors have no conflicts of interest to declare.

\section{Funding Sources}

This work is funded by the University Hospital Zurich, Department of Gynecology, Switzerland.

\section{Author Contributions}

Valerie Bernays designed the research study, collected the data, performed the analysis, and wrote the paper. Isabel Kolm contributed essential reagents or tools, analyzed the data, and edited the paper. Cornelia Betschart collected the data and edited the paper. Mariusz Pawel Kowalewski contributed essential reagents and tools and edited the paper. Ioannis Dedes and Daniel Fink edited the paper. Katrin Kerl analyzed the data. All authors have read and approved the final manuscript.

\section{References}

The corrections made in this section will be reviewed by journal production editor.

[1] Anemüller W, Recke A, Altgassen C, Kelling K. Developing an interdisciplinary consultation service for vulvar disorders. J Dtsch Dermatol Ges. 2012 May 1;10(5):350-7. http://dx.doi.org/10.1111/j.1610-0 
[2] Nardelli A, Degreef H, Goossens A. Contact allergic reactions of the vulva: a 14-year review. Dermatitis. 2004 Sep;15(3):131-6. http://dx.doi.org/10.2310/6620.2004.04004.

[3] Salim A, Wojnarowska F. Skin diseases affecting the vulva. Curr Obstet Gynaecol. 2002;12(2):81-9. htt p://dx.doi.org/10.1054/cuog.2001.0239.

[4] Pichardo-Geisinger R. Atopic and contact dermatitis of the vulva. Obstet Gynecol Clin North Am. 2017 Sep 1;44(3):371-8. http://dx.doi.org/10.1016/j.ogc.2017.05.003.

[5] Rimoin LP, Kwatra SG, Yosipovitch G. Female-specific pruritus from childhood to postmenopause: clinical features, hormonal factors, and treatment considerations. Dermatol Ther. 2013 Mar 1;26(2):15767. http://dx.doi.org/10.1111/dth.12034.

[6] Weidinger S, Novak N. Atopic dermatitis. Lancet. 2016 Mar 12;387(10023):1109-22. http://dx.doi.org/1 $\underline{0.1016 / \mathrm{S} 0140-6736}(\underline{15}) \underline{00149-\mathrm{X}}$.

[7] Schäcke H, Döcke WD, Asadullah K. Mechanisms involved in the side effects of glucocorticoids. Pharmacol Ther. 2002 Oct 1;96(1):23-43. http://dx.doi.org/10.1016/s0163-7258(므) $\underline{00297-8}$.

[8] Britz MB, Maibach HI. Human cutaneous vulvar reactivity to irritants. Contact Derm. 1979 Dec 1;5(6):375-7. http://dx.doi.org/10.1111/j.1600-0536.1979.tb04908.x.

[9] Sand FL, Thomsen SF. Skin diseases of the vulva: eczematous diseases and contact urticaria. J Obstet Gynaecol. 2018 Apr 3;38(3):295-300. http://dx.doi.org/10.1080/01443615.2017.1329283.

[10] Barnes PJ, Adcock IM. Glucocorticoid resistance in inflammatory diseases. Lancet. 2009 May

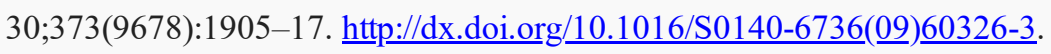

[11] Hollenberg SM, Weinberger C, Ong ES, Cerelli G, Oro A, Lebo R, et al. Primary structure and expression of a functional human glucocorticoid receptor cDNA. Nature. 1985 Dec 19;318(6047):63541. http://dx.doi.org/10.1038/318635a0 .

[12] Kumar R, Thompson EB. Gene regulation by the glucocorticoid receptor: structure, function, relationship. J Steroid Biochem Mol Biol. 2005 Apr;94(5):383-94.

[13] Oakley RH, Cidlowski JA. Cellular processing of the glucocorticoid receptor gene and protein: new mechanisms for generating tissue-specific actions of glucocorticoids. J Biol Chem. 2011 Feb 4;286(5):3177-84. http://dx.doi.org/10.1074/jbc.R110.179325.

[14] Kubin ME, Hägg PM, Kokkonen N, Väyrynen JP, Haapasaari KM, Moilanen J, et al. Glucocorticoid receptors GR $\alpha$ and GR $\beta$ are expressed in inflammatory dermatoses. Eur J Dermatol. 2016;26(1):21-7. $\underline{\text { ht }}$ tp://dx.doi.org/10.1684/ejd.2015.2691.

[15] Fakhri S, Tulic M, Christodoulopoulos P, Fukakusa M, Frenkiel S, Leung DY, et al. Microbial superantigens induce glucocorticoid receptor beta and steroid resistance in a nasal explant model. Laryngoscope. 2004 May 1;114(5):887-92. http://dx.doi.org/10.1097/00005537-200405000-00019.

[16] Christodoulopoulos P, Leung DY, Elliott MW, Hogg JC, Muro S, Toda M, et al. Increased number of glucocorticoid receptor-beta-expressing cells in the airways in fatal asthma. J Allergy Clin Immunol. 2000 Sep 1;106(3):479-84. http://dx.doi.org/10.1067/mai.2000.109054.

[17] Hägg PM, Hurskainen T, Palatsi R, Ilves M, Oikarinen A. Increased expression of glucocorticoid receptor beta in lymphocytes of patients with severe atopic dermatitis unresponsive to topical corticosteroid. Br J Dermatol. 2010 Feb 1;162(2):318-24. http://dx.doi.org/10.1111/j.1365-2133.2009.09 518.x.

[18] Boardman C, Chachi L, Gavrila A, Keenan CR, Perry MM, Xia YC, et al. Mechanisms of glucocorticoid action and insensitivity in airways disease. Pulm Pharmacol Ther. 2014 Dec 1;29(2):129- 
[19] van der Meijden WI, Boffa MJ, Ter Harmsel WA, Kirtschig G, Lewis FM, Moyal-Barracco M, et al. 2016 European guideline for the management of vulval conditions. J Eur Acad Dermatol Venereol. 2017 Jun 1;31(6):925-41. http://dx.doi.org/10.1111/jdv.14096.

[20] Varghese F, Bukhari AB, Malhotra R, De A. IHC profiler: an open source plugin for the quantitative evaluation and automated scoring of immunohistochemistry images of human tissue samples. PLoS One. 2014;9(5):e96801. http://dx.doi.org/10.1371/journal.pone.0096801.

[21] Seyed Jafari SM, Hunger RE. IHC optical density score: a new practical method for quantitative immunohistochemistry image analysis. Appl Immunohistochem Mol Morphol. 2017 Jan;25(1):e12-3. htt p://dx.doi.org/10.1097/PAI.0000000000000370.

[22] Sousa AR, Lane SJ, Cidlowski JA, Staynov DZ, Lee TH. Glucocorticoid resistance in asthma is associated with elevated in vivo expression of the glucocorticoid receptor beta-isoform. J Allergy Clin Immunol. 2000 May 1;105(5):943-50. http://dx.doi.org/10.1067/mai.2000.106486.

[23] Kozaci DL, Chernajovsky Y, Chikanza IC. The differential expression of corticosteroid receptor isoforms in corticosteroid-resistant and-sensitive patients with rheumatoid arthritis. Rheumatology. 2007 Apr;46(4):579-85.

[24] Johannesson U, Sahlin L, Masironi B, Hilliges M, Blomgren B, Rylander E, et al. Steroid receptor expression and morphology in provoked vestibulodynia. Am J Obstet Gynecol. 2008 Mar 1;198(3):3116. http://dx.doi.org/10.1016/j.ajog.2007.09.041.

[25] Oakley RH, Cidlowski JA. The biology of the glucocorticoid receptor: new signaling mechanisms in health and disease. J Allergy Clin Immunol. 2013;132(5):1033. http://dx.doi.org/10.1016/j.jaci.2013.09.0 $\underline{07}$.

[26] Brulefert A, Le Jan S, Plée J, Durlach A, Bernard P, Antonicelli F, et al. Variation of the epidermal expression of glucocorticoid receptor-beta as potential predictive marker of bullous pemphigoid outcome. Exp Dermatol. 2017 Dec 1;26(12):1261-6. http://dx.doi.org/10.1111/exd.13444.

[27] Lewis-Tuffin LJ, Cidlowski JA. The physiology of human glucocorticoid receptor beta (hGRbeta) and glucocorticoid resistance. Ann N Y Acad Sci. 2006 Jun 1;1069(1):1-9. http://dx.doi.org/10.1196/annals. $\underline{1351.001 .}$

[28] Pujols L, Mullol J, Roca-Ferrer J, Torrego A, Xaubet A, Cidlowski JA, et al. Expression of glucocorticoid receptor alpha- and beta-isoforms in human cells and tissues. Am J Physiol Cell Physiol. 2002 Oct;283(4):C1324-31. http://dx.doi.org/10.1152/ajpcell.00363.2001.

[29] Slominski RM, Robert, Tuckey C, Pulak, Manna R, Jetten AM, et al. Extra-adrenal glucocorticoid biosynthesis: implications for autoimmune and inflammatory disorders. Genes Immun. 2020;21(3):15068. http://dx.doi.org/10.1038/s41435-020-0096-6.

[30] Slominski A, Zjawiony J, Wortsman J, Semak I, Stewart J, Pisarchik A, et al. A novel pathway for sequential transformation of 7-dehydrocholesterol and expression of the P450scc system in mammalian skin. Eur J Biochem. 2004;271(21):4178-88. http://dx.doi.org/10.1111/j.1432-1033.2004.04356.x.

[31] Slominski A, Zbytek B, Szczesniewski A, Semak I, Kaminski J, Sweatman T, et al. CRH stimulation of corticosteroids production in melanocytes is mediated by ACTH. Am J Physiol Endocrinol Metab. 2005;288(4):E701-6. http://dx.doi.org/10.1152/ajpendo.00519.2004.

[32] Skobowiat C, Dowdy JC, Sayre RM, Tuckey RC, Slominski A. Cutaneous hypothalamic-pituitaryadrenal axis homolog: regulation by ultraviolet radiation. Am J Physiol Endocrinol Metab. 2011 Sep;301(3):E484-93. http://dx.doi.org/10.1152/ajpendo.00217.2011. 
Al Heialy S, Gaudet M, Ramakrishnan RK, Mogas A, Salameh L, Mahboub B, et al. Contribution of IL-17 in steroid hyporesponsiveness in obese asthmatics through dysregulation of glucocorticoid receptors $\alpha$ and $\beta$. Front Immunol. 2020;11:1724. http://dx.doi.org/10.3389/fimmu.2020.01724.

[34] Wang Z, Wang C, Wang Y, Mo B, Wei J, Ma L, et al. E4BP4 facilitates glucocorticoid sensitivity of human bronchial epithelial cells via down-regulation of glucocorticoid receptor-beta. Cell Immunol. 2018 Dec 1;334:31-7. http://dx.doi.org/10.1016/j.cellimm.2018.08.015.

[35] Kino T, Manoli I, Kelkar S, Wang Y, Su YA, Chrousos GP. Glucocorticoid receptor (GR) $\beta$ has intrinsic, GR $\alpha$-independent transcriptional activity. Biochem Biophys Res Commun. 2009 Apr 17;381(4):671-5.

[36] Dréno B, Araviiskaia E, Berardesca E, Gontijo G, Sanchez Viera M, Xiang LF, et al. Microbiome in healthy skin, update for dermatologists. J Eur Acad Dermatol Venereol. 2016;30(12):2038. http://dx.doi. org $/ 10.1111 / \mathrm{j} \underline{\mathrm{dv} .13965}$.

[37] Taniguchi Y, Iwasaki Y, Tsugita M, Nishiyama M, Taguchi T, Okazaki M, et al. Glucocorticoid receptor- $\beta$ and receptor- $\gamma$ exert dominant negative effect on gene repression but not on gene induction. Endocrinology. 2010 Jul;151(7):3204-13. http://dx.doi.org/10.1210/en.2009-1254.

[38] Leung DY, Hamid Q, Vottero A, Szefler SJ, Surs W, Minshall E, et al. Association of glucocorticoid insensitivity with increased expression of glucocorticoid receptor beta. J Exp Med. 1997 Nov 3;186(9):1567-74. http://dx.doi.org/10.1084/jem.186.9.1567.

[39] Hamid QA, Wenzel SE, Hauk PJ, Tsicopoulos A, Wallaert B, Lafitte JJ, et al. Increased glucocorticoid receptor beta in airway cells of glucocorticoid-insensitive asthma. Am J Respir Crit Care Med. 1999 May 14;159(5 Pt 1):1600-4. http://dx.doi.org/10.1164/ajrccm.159.5.9804131.

[40] Honda M, Orii F, Ayabe T, Imai S, Ashida T, Obara T, et al. Expression of glucocorticoid receptor beta in lymphocytes of patients with glucocorticoid-resistant ulcerative colitis. Gastroenterology. 2000 May;118(5):859-66. http://dx.doi.org/10.1016/s0016-5085(므)0172-7.

[41] Orii F, Ashida T, Nomura M, Maemoto A, Fujiki T, Ayabe T, et al. Quantitative analysis for human glucocorticoid receptor alpha/beta mRNA in IBD. Biochem Biophys Res Commun. 2002 Sep 6;296(5):1286-94. http://dx.doi.org/10.1016/s0006-291x $(\underline{02}) \underline{02030-2}$.

[42] Man XY, Li W, Chen JQ, Zhou J, Landeck L, Zhang KH, et al. Impaired nuclear translocation of glucocorticoid receptors: novel findings from psoriatic epidermal keratinocytes. Cell Mol Life Sci. 2013 Jun 19;70(12):2205-20. http://dx.doi.org/10.1007/s00018-012-1255-3.

[43] Labrie F, Martel C, Bélanger A, Pelletier G. Androgens in women are essentially made from DHEA in each peripheral tissue according to intracrinology. J Steroid Biochem Mol Biol. 2017;168:9-18.

[44] Santoro S, Lopez ID, Lombardi R, Zauli A, Osiceanu AM, Sorosina M, et al. Laser capture microdissection for transcriptomic profiles in human skin biopsies. BMC Molecular Biol. 2018;19(1):7. $\underline{\mathrm{h}}$ ttp://dx.doi.org/10.1186/s12867-018-0108-5.

[45] Lewis-Tuffin LJ, Jewell CM, Bienstock RJ, Collins JB, Cidlowski JA. Human glucocorticoid receptor beta binds RU-486 and is transcriptionally active. Mol Cell Biol. 2007 Mar;27(6):2266-82. http://dx.doi. org/10.1128/MCB.01439-06.

\section{Queries and Answers}


Query: References 31 was not cited in the text, Please indicate where to place the citation.

Answer: Reference 31 should be in the discussion in the third paragraph after the word ACTH.

31 should be written there instead of reference 32 . 